\title{
Differential Effects of Palmitoylethanolamide against Amyloid- $\beta$ Induced Toxicity in Cortical Neuronal and Astrocytic Primary Cultures from Wild-Type and 3xTg-AD Mice
}

\author{
Maria Cristina Tomasini ${ }^{\mathrm{a}, \mathrm{b}}$, Andrea Celeste Borelli ${ }^{\mathrm{c}}$, Sarah Beggiato ${ }^{\mathrm{a}, \mathrm{b}}$, Luca Ferraro $^{\mathrm{a}, \mathrm{b}, \mathrm{d}}$, \\ Tommaso Cassano ${ }^{\mathrm{e}}$, Sergio Tanganelli ${ }^{\mathrm{b}, \mathrm{c}, \mathrm{d}}$ and Tiziana Antonelli ${ }^{\mathrm{b}, \mathrm{c}, \mathrm{d}, *}$ \\ ${ }^{\mathrm{a}}$ Department of Life Sciences and Biotechnology, University of Ferrara, Italy \\ b IRET Foundation, Ozzano Emilia, Bologna, Italy \\ ${ }^{\mathrm{c}}$ Department of Medical Sciences, University of Ferrara, Italy \\ ${ }^{\mathrm{d}}$ LTTA Centre, University of Ferrara, Italy \\ ${ }^{\mathrm{e}}$ Department of Clinical and Experimental Medicine, University of Foggia, Italy
}

Handling Associate Editor: Patrizia Mecocci

Accepted 23 February 2015

\begin{abstract}
.
Background: Considering the heterogeneity of pathological changes occurring in Alzheimer's disease (AD), a therapeutic approach aimed both to neuroprotection and to neuroinflammation reduction may prove effective. Palmitoylethanolamide (PEA) has attracted attention for its anti-inflammatory/neuroprotective properties observed in AD animal models.

Objective and Methods: We evaluated the protective role of PEA against amyloid- $\beta_{42}\left(A \beta_{42}\right)$ toxicity on cell viability and glutamatergic transmission in primary cultures of cerebral cortex neurons and astrocytes from the triple-transgenic murine model of $\mathrm{AD}(3 \mathrm{xTg}-\mathrm{AD})$ and their wild-type littermates (non-Tg) mice.

Results: $\mathrm{A} \beta_{42}(0.5 \mu \mathrm{M} ; 24 \mathrm{~h})$ affects the cell viability in cultured cortical neurons and astrocytes from non-Tg mice, but not in those from $3 \times$ Tg-AD mice. These effects were counteracted by the pretreatment with PEA $(0.1 \mu \mathrm{M})$. Basal glutamate levels in cultured neurons and astrocytes from 3xTg-AD mice were lower than those observed in cultured cells from non-Tg mice. $A \beta_{42}$-exposure reduced and increased glutamate levels in non-Tg mouse cortical neurons and astrocytes, respectively. These effects were counteracted by the pretreatment with PEA. By itself, PEA did not affect cell viability and glutamate levels in cultured cortical neuron and astrocytes from non-Tg or 3xTg-AD mice.

Conclusion: The exposure to $A \beta_{42}$ induced toxic effects on cultured cortical neurons and astrocytes from non-Tg mice, but not in those from 3xTg-AD mice. Furthermore, PEA exerts differential effects against $A \beta_{42}$-induced toxicity in primary cultures of cortical neurons and astrocytes from non- $\mathrm{Tg}$ and $3 \mathrm{xTg}-\mathrm{AD}$ mice. In particular, PEA displays protective properties in non- $\mathrm{Tg}$ but not in 3xTg-AD mouse neuronal cultured cells overexpressing $\mathrm{A} \beta$.
\end{abstract}

Keywords: Alzheimer's disease, cell viability, GFAP immunoreactivity, glutamate, MAP2 immunoreactivity

\footnotetext{
${ }^{*}$ Correspondence to: Dr. Tiziana Antonelli, MD, Department of Medical Sciences, Section of Pharmacology, University of Ferrara,
}

Via Fossato di Mortara 17-19, 44121 Ferrara, Italy. Tel.: +390532 455207; Fax: +39 0532 455205; E-mail: ant@ unife.it. 


\section{INTRODUCTION}

Alzheimer's disease (AD) is an age-dependent, multifactorial neurodegenerative pathology resulting in the deterioration of selective cognitive performance including memory, and learning impairment [1-3]. The neurodegenerative process in $\mathrm{AD}$ is characterized by the presence of two classes of abnormal structures: extracellular amyloid plaques surrounded by activated microglia, reactive astrocytes, dystrophic neurites, and degenerating neurons [4], along with intraneuronal neurofibrillary tangles subsequent to an abnormal tau protein phosphorylation [5-7]. Although the classical so-called "amyloid cascade hypothesis" has been recently revisited, a large body of evidence suggests that the overexpression of the amyloid- $\beta$ protein precursor $(\mathrm{A} \beta \mathrm{PP})$ and subsequent generation of amyloid- $\beta(A \beta)$ fragments is central to the neurodegeneration observed in $\mathrm{AD}$ patients. $\mathrm{A} \beta$ appears to exert some of its neurotoxic effects through numerous secondary pathways, including tau hyperphosphorylation and neurofibrillary tangle formation, oxidation, inflammation, demyelination, and excitotoxicity. For instance, both in vitro and in vivo findings have demonstrated that $A \beta$ fragments promote a marked neuroinflammatory response, sustained by glial cells, accounting for the synthesis of different cytokines and proinflammatory mediators $[8,9]$. As astrocytes outnumber microglia in the brain and their activation seems to last longer, they may have a more important and sustained role over microglia in the enduring neuroinflammation in $\mathrm{AD}$ [10]. The secreted proinflammatory factors and alterations in the expression of several proteins that support and accelerate the neurodegenerative events [11], make neurons particularly vulnerable to cytotoxic events, including glutamate excitotoxicity [12]. In fact, it is well demonstrated that a sustained increase in extracellular glutamate levels, associated with overstimulation of N-methylD-aspartate (NMDA) receptors, may represent an additional pathogenetic basis of neurodegeneration in $\mathrm{AD}$ [13]. In this context, it is worth noting that astrocytes exert a central role in brain homeostasis, in particular via the numerous cooperative metabolic processes that they establish with neurons, such as the supply of energy metabolites and neurotransmitter recycling functions. Thus, it has been reported that impairments in astrocytic function play an important role in neuronal dysfunction, and could contribute to excitotoxic phenomena observed in the neurodegenerative processes [14]. In view of the above, it seems clear that the neuroinflammatory process sustained by excessive and prolonged astrocyte activation might alter neuron/astrocyte cooperation, thus causing deleterious effects on neurons and contributing to the $\mathrm{AD}$ neuronal cell loss. A therapeutic approach aimed both to neuroprotection and neuroinflammation reduction may therefore prove effective in slowing the progression of the disease [15].

Cannabinoids (CBs) or the modulation of the endocannabinoid signals have been proposed as possible therapeutic approaches to AD [16-18]. The endocannabinoid system is extensively involved in the neuroinflammatory process, exerting an inhibitory and neuroprotective role both at the peripheral level, by modulating plasma and tissue immune cells, and on central glial cells $[19,20]$. Anti-inflammatory and neuroprotective functions have been particularly attributed to the endocannabinoids belonging to the acylethanolamide family, like anandamide as well as to anandamide congeners oleoylethanolamide and palmitoylethanolamide (PEA), since their production is greatly increased in the sites of neuronal damage [21]. In the central nervous system, PEA, produced by neurons, microglia, and astrocytes, exerts a local anti-injury function through a down-modulation of mast cells and by protecting neurons from excitotoxicity [22-24]. However, its exact biological roles remain elusive. Recently, PEA has been defined as a cannabinoid receptor-inactive endocannabinoidrelated molecule [23], with different mechanisms of action such as the activation of a cell surface receptor [CB2-like or the G-protein coupled receptor 55, orphan (GPR55)] [25], the activation of a nuclear receptor of the peroxisome proliferator-activated receptor (PPAR) family $[26,27]$ and the action as "entourage" compound enhancing endocannabinoid activity at their receptors and/or inhibiting endocannabinoid degradation [28]. In addition, in vitro and in vivo results have suggested anti-inflammatory and neuroprotective properties of PEA against $A \beta$-induced neurotoxicity [29-32]. On the contrary, there are not exhaustive data on the possible neuroprotective effects of PEA in genetically modified mouse model of AD.

The triple-transgenic murine model of $\mathrm{AD}(3 \mathrm{xTg}$ $\mathrm{AD}$ ), which harbors three mutant human genes $\left(\mathrm{A} \beta \mathrm{PP}_{\mathrm{Swe}}, \mathrm{PS}_{\mathrm{M} 146 \mathrm{~V}}\right.$, taup301L) closely mimics many aspects of $A D$ in humans. In fact, these animals are characterized by age-dependent build-up of both plaques and tangles in the cerebral cortex, hippocampus, and amygdala regions [33, 34]. Moreover, evidence of progressive deficits in synaptic plasticity and in cognitive functions has been shown in the $3 \times \mathrm{Tg}$ $\mathrm{AD}$ mice $[33,35]$. It has also been reported that the 
primary neuronal cultures from $3 \times \mathrm{Tg}$-AD mice represent the first in vitro model of $\mathrm{AD}$ characterized by a simultaneous overexpression of $\mathrm{A} \beta \mathrm{PP}, \mathrm{A} \beta$, and tau protein useful to evaluate cellular and molecular mechanisms associated with the pathology of $\mathrm{AD}$ in order to investigate new pharmacological approaches [34].

Based on the above findings, the main aim of the present study was to assess the protective effects of PEA on $A \beta_{42}$-induced toxicity by studying cell viability and morphology. Moreover the ability of PEA to modulate the function of cortical glutamatergic neurons and astrocytes, by measuring basal endogenous glutamate release, was evaluated. All experiments were carried out in primary cultures of neurons and astrocytes obtained from the cerebral cortex of wild-type (non-Tg) and 3xTg-AD mice. The cerebral cortex was chosen as the most representative area among the brain regions affected by $\mathrm{AD}$.

\section{MATERIALS AND METHODS}

\section{Animals}

Colonies of 3xTg-AD mice and wild type littermates (non-Tg) were established at the animal facilities of the Puglia and Basilicata Experimental Zooprophylactic Institute (Foggia, Italy), according to the procedures previously described [36]. The 3xTg-AD mice harboring $\mathrm{A} \beta \mathrm{PP}_{\mathrm{swe}}, \mathrm{PS}_{\mathrm{M} 146 \mathrm{~V}}$, and tau $301 \mathrm{~L}$ transgenes were genetically engineered by LaFerla and colleagues at the Department of Neurobiology and Behavior, University of California, Irvine [33, 37]. Genotypes were confirmed by polymerase chain reaction (PCR) after tail biopsies [33]. The housing conditions were controlled (temperature $22^{\circ} \mathrm{C}$, light from 07:00-19:00, humidity $50 \%-60 \%$ ), and fresh food and water were freely available.

Experiments were carried out in strict accordance with the European Communities Council Directive (86/609/EEC) and the Guidelines released by the Italian Ministry of Health (D.L. 116/92) and (D.L. 111/94-B). A formal approval to conduct the experiments described was obtained by the local Ethics Committee (University of Ferrara, Italy). Efforts were made to minimize the number of animals used and to reduce their discomfort.

\section{Primary cultures of cerebral cortical neurons}

Primary cultures of cortical neurons were prepared from embryonic day 18 (E18) non-Tg and 3xTg-AD mouse embryos and cultured as previously described
[38]. Cortices free of meninges were dissociated in $0.025 \%(\mathrm{w} / \mathrm{v})$ trypsin at $37^{\circ} \mathrm{C}$ followed by mechanical repeated gentle pipetting through wide- and narrowbore fire-polished Pasteur pipettes in culture medium [Neurobasal medium (Gibco, Grand Island, NY, USA) supplemented with $0.1 \mathrm{mM}$ glutamine (Sigma Chemical Co., St. Louis, MO, USA), $10 \mu \mathrm{g} / \mathrm{ml}$ gentamicin (Sigma Chemical Co.) and 2\% B-27® Supplement (50X), serum free $(\mathrm{Gibco} 囚)]$. Cells were counted and then plated on poly-L-lysine $(5 \mu \mathrm{g} / \mathrm{ml})$-coated multiwells ( 24 wells; Nunc A/S, Roskilde, Denmark) at a density of 200,000 cells per well and on 96-well at a density of 50,000 cells per well. For immunocytochemistry, the cells were plated on glass coverslips at a concentration of 200,000 cells per well. Cultures were grown at $37^{\circ} \mathrm{C}$ in a humidified atmosphere, $5 \%$ $\mathrm{CO}_{2} / 95 \%$ air. Cytosine arabinoside $(10 \mu \mathrm{M}$; Sigma Chemical Co.) was added within $24 \mathrm{~h}$ of plating to prevent glial cell proliferation. After 8 days of in vitro incubation (days in vitro: DIV), cultures were used for experiments.

\section{Primary cultures of cerebral cortical astrocytes}

Primary cultures of cerebral cortical astrocytes were obtained from newborn non-Tg and 3xTg-AD mice (1 or 2 days old) and cultured as described by Scuderi et al. [30], with slight modifications. Cerebral cortices were removed and dissociated by mild trypsinization at $37^{\circ} \mathrm{C}$, followed by mechanical trituration to obtain single cells. Cells were suspended in the culture medium [DMEM, 5\% inactivated fetal bovine serum (Gibco), $100 \mathrm{IU} / \mathrm{ml}$ penicillin, and $100 \mu \mathrm{g} / \mathrm{ml}$ streptomycin (all from Sigma-Aldrich, Milan, Italy)] and then seeded in $75-\mathrm{cm}^{2}$ flasks at a density of $3 \times 10^{6}$ cells/flask. The cells were incubated at $37^{\circ} \mathrm{C}$ in a humidified atmosphere, $5 \% \mathrm{CO}_{2} / 95 \%$ air. The culture medium was replaced after $24 \mathrm{~h}$ and again twice weekly until astrocytes were grown to form a monolayer firmly attached to the bottom of the flask (12 or 14 days after dissection). At cell confluence, flasks were vigorously shaken to separate astrocytes (which remained adherent in the bottom of the flasks) from microglia and oligodendrocytes (which floated on the supernatant). Collected astrocytes were counted and then plated on poly-L-lysine $(5 \mu \mathrm{g} / \mathrm{ml})$-coated multiwells (24 wells) at a density of 200,000 cells per well and on 96-multiwell plates at a density of 50,000 cells per well. For immunocytochemistry, the cultured astrocytes were plated on glass coverslips at a concentration of 200,000 cells per well. The purity of the cells in culture was tested with monoclonal anti-glial 
fibrillary acidic protein (GFAP) and only cultures with more than 95\% GFAP-positive cells were used for the experiments.

\section{Neuronal and astroglial culture pharmacological treatments}

Both neuronal and astroglial cultures were treated with $A \beta_{42}(0.5 \mu \mathrm{M}$; Tocris Bioscience, Bristol, UK) for $24 \mathrm{~h}$ with or without PEA $(0.1 \mu \mathrm{M}$; Tocris Bioscience, Bristol, UK), added $1 \mathrm{~h}$ before $A \beta_{42}$ and maintained in contact with the cells during the peptide exposure. The concentration of the substances was chosen according to previous results [29, 30]. Cell viability, cell count and glutamate levels were assessed after $24 \mathrm{~h}$ of treatment.

\section{Neutral red assay}

The neutral red assay was used to assess cell viability [31, 39]. Cells were cultured in 96-multiwell plates and treated as described above. $24 \mathrm{~h}$ after pharmacological treatments, the plates were incubated for $3 \mathrm{~h}$ at $37^{\circ} \mathrm{C}$ with a neutral red working solution $(50 \mu \mathrm{g} \mathrm{ml}-1$ in PBS $1 \mathrm{X}$ without calcium and magnesium, SigmaAldrich, St. Louis, MO, USA). The cells were washed and the dye removed from each well through a destain solution (ethanol:deionized water: glacial acetic acid, 50:49:1, v/v). The absorbance was read at $540 \mathrm{~nm}$ using a microplate absorbance reader (Sunrise, Tecan). The values of treated cells were referred to control non-exposed cultures, and expressed as percentage variation.

\section{Immunocytochemistry}

Cells were rinsed in $0.1 \mathrm{M}$ PBS and then fixed with $4 \%$ paraformaldehyde in Sorensen's buffer $0.1 \mathrm{M}$,

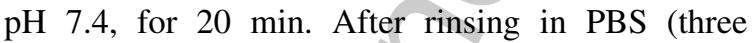
times for $5 \mathrm{~min}$ each), the cells were incubated overnight at $4{ }^{\circ} \mathrm{C}$ in $0.3 \%$ Triton $\mathrm{X}-100 / \mathrm{PBS}$ solution $(\mathrm{v} / \mathrm{v})$ containing the following primary antibodies: anti-microtubule-associated protein 2 (MAP2) (1:1000 dilution, Chemicon, Temecula, CA) and anti-GFAP (1:200 dilution Chemicon, Temecula, CA). The cells were then washed three times with PBS and incubated for $60 \mathrm{~min}$ at room temperature with the proper secondary antibodies: rhodamine-conjugated anti-rabbit antibody (1:100 dilution Chemicon, Temecula, CA) and fluorescein isothiocyanate-conjugated anti-mouse antibody (1:100 dilution Chemicon, Temecula, CA), respectively. Nuclei were stained with Hoechst 33258
( $1 \mu \mathrm{g} / \mathrm{ml}$; Sigma Aldrich, St. Louis, MO, USA) added to the secondary antibody solution. After 3 washes in PBS, the cells were mounted in glycerol and PBS (3:1, $\mathrm{v} / \mathrm{v}$ ) containing $0.1 \%$ 1,4-phenylenediamine and examined using a Nikon Microphot FXA microscope. For cell counts, five separate non-overlapping fields were randomly chosen in each coverslip and the images were taken using the $\mathrm{x} 20$ objective.

Anti-MAP2 antibody, anti-GFAP antibody, rhodamine-conjugated anti-rabbit antibody, and fluorescein isothiocyanate-conjugated anti-mouse antibody were purchased from Chemicon, Temecula, CA.

\section{Endogenous extracellular glutamate levels}

On the day of the experiment, cells were rinsed twice ( $1 \mathrm{~min} / \mathrm{rinse}$ ) by replacing the culture medium with a warmed $\left(37^{\circ} \mathrm{C}\right)$ Krebs Ringer-bicarbonate buffer (mM: $\mathrm{NaCl} 118.5, \mathrm{KCl} 4.8, \mathrm{CaCl}_{2} 2.5, \mathrm{MgSO}_{4} 1.2, \mathrm{NaHCO}_{3}$ $25, \mathrm{NaH}_{2} \mathrm{PO}_{4}$ 1.2, glucose 11, pH 7.4). Thereafter, $400 \mu \mathrm{l}$ of this solution were added to each plates and, after $50 \mathrm{~min}, 100 \mu \mathrm{l}$ of the solution were collected. After rinsing, the procedure was repeated to collect a second 50 min fraction. Then, cells were treated by adding $400 \mu l$ of Krebs Ringer-bicarbonate buffer containing $\mathrm{A} \beta_{42}(0.5 \mu \mathrm{M})$ and/or PEA $(0.1 \mu \mathrm{M})$ and a third fraction was collected $24 \mathrm{~h}$ later. Control cell cultures were treated with Krebs Ringer-bicarbonate buffer. The first two fractions were used to assess basal endogenous glutamate levels. The effects of the treatments on endogenous extracellular glutamate levels during the third fraction were reported and expressed as percentage changes of basal values, as calculated by the means of the two fractions collected prior to treatment. Endogenous glutamate levels were quantified using a high-performance liquid chromatography/fluorimetric detection system, including a precolumn derivatization o-phthaldialdehyde reagent and a Chromsep 5 (C18) column ( $3 \mathrm{~mm}$ internal diameter; $10 \mathrm{~cm}$ length). The mobile phase (flow: $0.75 \mathrm{ml} / \mathrm{min}$ ) consisted of $0.1 \mathrm{M}$ sodium acetate, $10 \%$ methanol, and $2.5 \%$ tetrahydrofuran, $\mathrm{pH}$ 6.5. For fluorimetric detection, excitation and emission wavelengths were set at 370 and $450 \mathrm{~nm}$, respectively. The limit of detection for glutamate was 30 fmol per sample [40].

\section{Statistical analysis}

Results are expressed as means \pm standard error of mean. The statistical analysis was carried out by analysis of variance (ANOVA) followed by the 
Newman-Keuls test for multiple comparisons. $p<0.05$ was the accepted level of significance.

\section{RESULTS}

Primary cultures of cerebral cortical neurons from $3 x T g-A D$ and non-Tg mice

Effects of $A \beta_{42}$ exposure in the presence and in the absence of PEA on cellular viability

The exposure to $A \beta_{42}(0.5 \mu \mathrm{M} ; 24 \mathrm{~h})$ induced a significant decrease in the cell viability in cultured cortical neurons obtained from non-Tg mice (Fig. 1A), but not in cultured cortical neurons obtained from $3 \times \mathrm{Tg}-\mathrm{AD}$ mice (Fig. 1B). Pretreatment with PEA $(0.1 \mu \mathrm{M})$ fully counteracted $A \beta_{42}$-induced decrease of cell viability in cultured cortical neurons obtained from non-Tg mice (Fig. 1A). By itself, PEA did not affect cell viability in cultured cortical neurons obtained from non-Tg mice (Fig. 1A) or 3xTg-AD mice (Fig. 1B).

Effects of $A \beta_{42}$ exposure in the presence and in the absence of PEA on endogenous extracellular glutamate levels

Basal extracellular glutamate levels in cultured cortical neurons obtained from non-Tg mice were significantly higher than those observed in cultured cortical neurons obtained from $3 \times \mathrm{Tg}-\mathrm{AD}$ mice $(0.328 \pm 0.029 \mu \mathrm{M}$ and $0.063 \pm 0.005 \mu \mathrm{M}$, respectively). $\mathrm{A} \beta_{42}(0.5 \mu \mathrm{M} ; 24 \mathrm{~h})$ exposure reduced extracellular glutamate levels in cultured cortical neurons obtained from non-Tg mice (Fig. 2A), but not in cultured cortical neurons obtained from $3 \times \mathrm{Tg}$ AD mice (Fig. 2B). Pretreatment with PEA $(0.1 \mu \mathrm{M})$ counteracted $A \beta_{42}$-induced decrease of extracellular glutamate levels in cultured cortical neurons obtained from non-Tg mice (Fig. 2A). By itself, PEA did not affect extracellular glutamate levels in cultured cortical neurons obtained from non-Tg mice (Fig. 2A) or 3xTg-AD mice (Fig. 2B).

Effects of $A \beta_{42}$ exposure in the presence and in the absence of PEA on MAP-2 immunoreactivity in cultured cortical neurons from non-Tg mice and $3 x T g-A D$ mice

In view of the above results, the possibility that $\mathrm{A} \beta_{42}$-exposure could affect morphological development and proliferation of cultured cortical neurons obtained from non- $\mathrm{Tg}$ mice, was explored. To this purpose, cultured cortical neurons were stained with an antibody for the neuronal marker MAP2, which can be considered an index of the integrity of the cytoskeleton

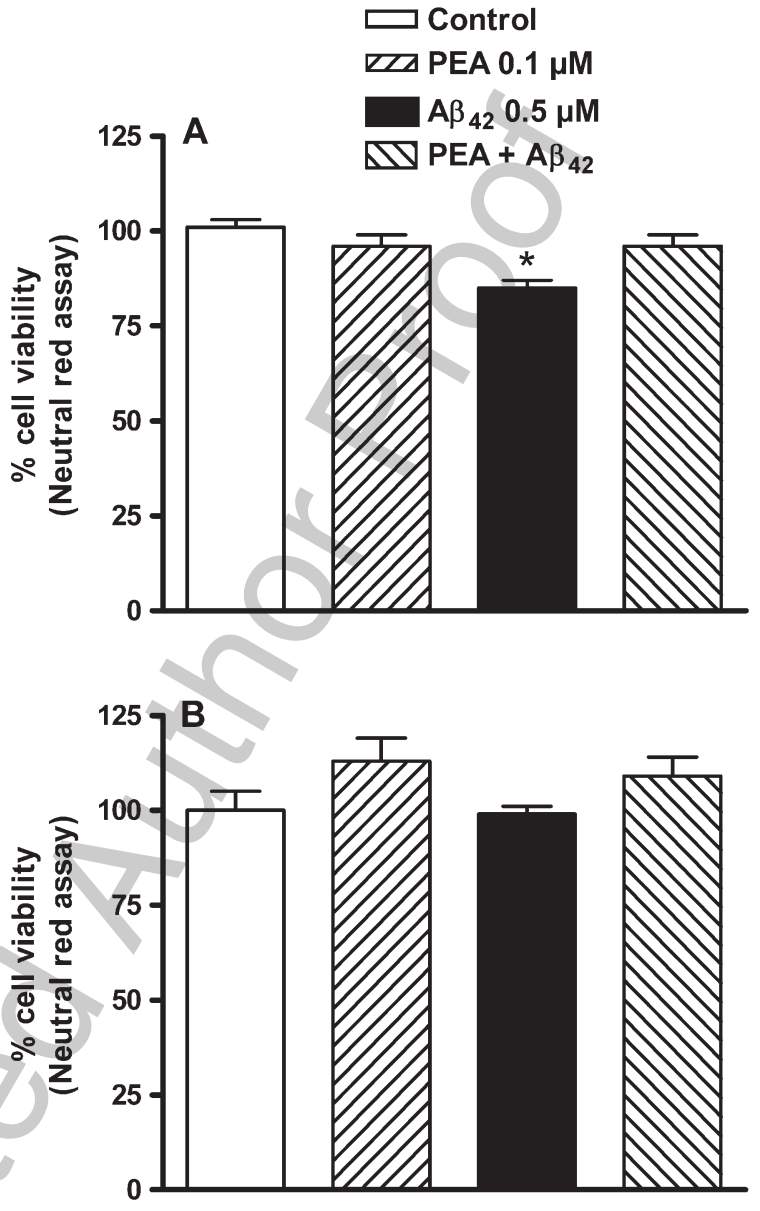

Fig. 1. Effects of $A \beta_{42}$ exposure $(0.5 \mu \mathrm{M} ; 24 \mathrm{~h})$, alone or in combination with PEA $(0.1 \mu \mathrm{M})$, on cell viability in primary cultures of cerebral cortical neurons from non-Tg (A) and 3xTg-AD (B) mice. PEA was added $1 \mathrm{~h}$ before $A \beta_{42}$ and maintained in contact with the cells during $A \beta_{42}$ exposure. Cell viability was assessed by Neutral red assay and expressed as percentage of control values. Each histogram represents the mean \pm S.E.M. $(n=30-40) .{ }^{*} p<0.05$ significantly different from control, PEA and PEA $+\mathrm{A} \beta_{42}$ groups according to analysis of variance followed by the Newman-Keuls test for multiple comparisons.

in $\mathrm{AD}$ [41]. Control cultured cortical neurons presented a high number of healthy neurons, which developed a complex neuronal network characterized by highly arborized dendritic trees and MAP2 immunoreactivity homogeneously distributed in the cell bodies and dendrites (Fig. 3). On the contrary, in cultured cortical neurons exposed to $A \beta_{42}(0.5 \mu \mathrm{M} ; 24 \mathrm{~h})$ the neuronal network appeared fragmented (Fig. 3). In particular, a dishomogeneous distribution of MAP2 immunoreactivity along the neurites was observed, and the dendrites often appeared truncated. To quantify the effect of $A \beta_{42}$, the number of vital MAP-2 immunostained cultured neurons was determined. As shown in 

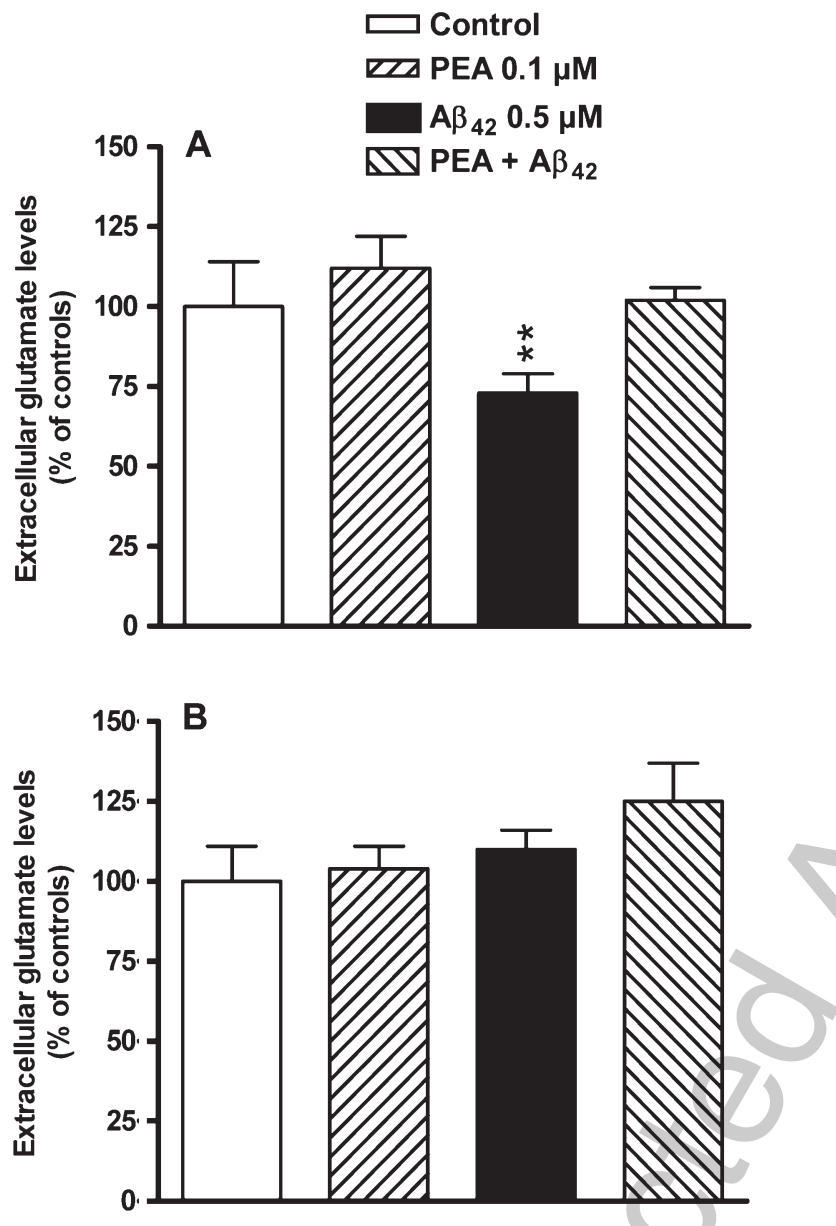

Fig. 2. Effects of $A \beta_{42}$ exposure $(0.5 \mu \mathrm{M} ; 24 \mathrm{~h})$, alone or in combination with PEA $(0.1 \mu \mathrm{M})$, on extracellular glutamate levels in primary cultures of cerebral cortical neurons from non- $\mathrm{Tg}(\mathrm{A})$ and 3xTg-AD (B) mice. PEA was added $1 \mathrm{~h}$ before $A \beta_{42}$ and maintained in contact with the cells during $A \beta_{42}$ exposure $(24 \mathrm{~h})$. Each histograms represents the mean \pm S.E.M. $(n=32-42) .{ }^{* *} p<0.01$ significantly different from control, PEA and PEA $+A \beta_{42}$ groups according to analysis of variance followed by the Newman-Keuls test for multiple comparisons.

Primary cultures of cerebral cortical astrocytes from $3 x T g-A D$ and non-Tg mice

Effects of $A \beta_{42}$ exposure in the presence and in the absence of PEA on cellular viability

$\mathrm{A} \beta_{42} \quad(0.5 \mu \mathrm{M} ; 24 \mathrm{~h})$ exposure significantly increased the astroglial proliferation, as indicated by the enhanced cell viability measured in cultured cortical astrocytes obtained from non-Tg mice (Fig. 6A). On the contrary, $A \beta_{42}$ exposure failed to modify the cell viability value in cultured cortical astrocytes obtained from 3xTg-AD mice (Fig. 6B). PEA pretreatment $(0.1 \mu \mathrm{M})$ counteracted $A \beta_{42}$-induced astroglial proliferation in cultured cortical astrocytes obtained from non-Tg mice (Fig. 6A). By itself, PEA did not affect cell viability in cultured cortical astrocytes obtained from non-Tg mice (Fig 6A) or 3xTg-AD mice (Fig. 6B).

Effects of $A \beta_{42}$ exposure in the presence and in the absence of PEA on endogenous extracellular glutamate levels

Basal extracellular glutamate levels in cultured cortical astrocytes obtained from non- $\mathrm{Tg}$ mice were significantly higher than those observed in cultured cortical astrocytes obtained from $3 \times \mathrm{Tg}-\mathrm{AD}$ mice $(1.994 \pm 0.122 \mu \mathrm{M}$ and $0.087 \pm 0.007 \mu \mathrm{M}$, respectively). $A \beta_{42}(0.5 \mu \mathrm{M} ; 24 \mathrm{~h})$ exposure increased extracellular glutamate levels in cultured cortical astrocytes obtained from non-Tg mice (Fig. 7A) but not in cultured cortical astrocytes obtained from $3 \mathrm{xTg}$ AD mice (Fig. 7B). Pretreatment with PEA $(0.1 \mu \mathrm{M})$ counteracted $A \beta_{42}$-induced increase of extracellular glutamate levels in cultured cortical astrocytes obtained from non-Tg mice (Fig. 7A). By itself, PEA did not affect extracellular glutamate levels in cultured cortical astrocytes obtained from non-Tg (Fig. 7A) or 3xTg-AD mice (Fig. 7B).

Fig. 4, the number of neurons was significantly lower in cell cultures exposed to $A \beta_{42}$ than in control cultures. Interestingly, pretreatment with PEA $(0.1 \mu \mathrm{M})$, by itself ineffective, counteracted $\mathrm{A} \beta_{42}$-induced decrease of neuron number (Fig. 4).

Finally, control cultured cortical neurons obtained from 3xTg-AD mice displayed morphological alterations similar to those observed in $\mathrm{A} \beta_{42}$-exposed cultured cortical neurons obtained from non-Tg mice (Fig. 5). The exposure to $A \beta_{42}(0.5 \mu \mathrm{M})$ or PEA $(0.1 \mu \mathrm{M})$ did not modify these alterations in cultured cortical neurons obtained from $3 \times \mathrm{Tg}-\mathrm{AD}$ mice (data not shown).
Effects of $A \beta_{42}$ exposure in the presence and in the absence of PEA on GFAP immunoreactivity in cultured cortical astrocytes from non-Tg mice and 3xTg-AD mice

Morphological changes induced by $A \beta_{42}$ exposure were also evaluated in GFAP immunostained cultured cortical astrocytes obtained from non-Tg and $3 \times \mathrm{Tg}-\mathrm{AD}$ mice. In control cultured cortical astrocytes, GFAP positive cells showed numerous branched processes, extending outward from the somata in multiple directions (stellate shape), that are typical of healthy astrocytes (Fig. 8). Following the exposure to $A \beta_{42}$ $(0.5 \mu \mathrm{M} ; 24 \mathrm{~h})$, the morphology of cultured astrocytes 

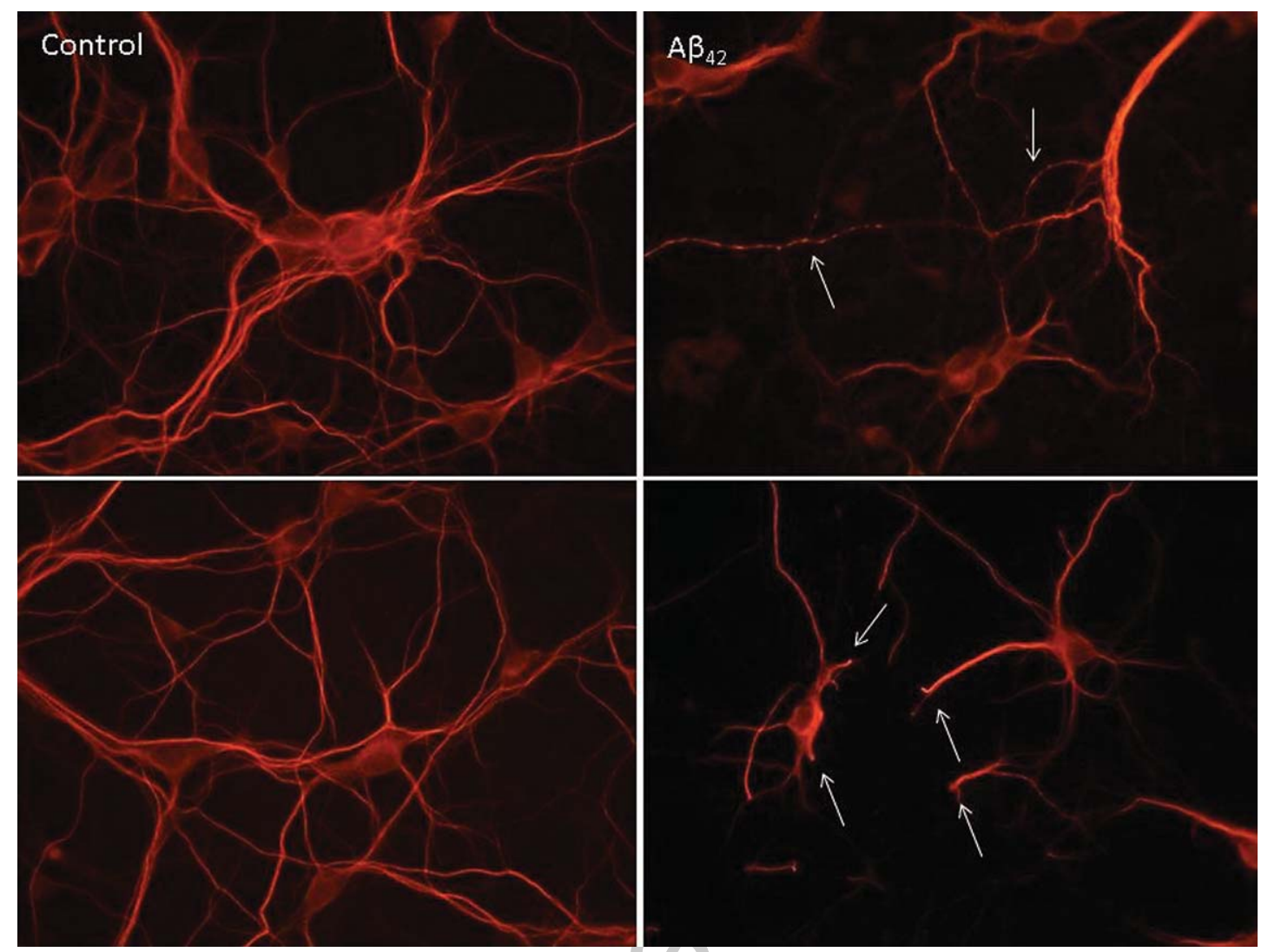

Fig. 3. Representative fluorescence photomicrographs of MAP2 immunoreactivity in primary cultures of cerebral cortical neurons from non-Tg mice not exposed (left panel) and exposed to $\mathrm{A} \beta_{42}(0.5 \mu \mathrm{M} ; 24 \mathrm{~h}$; right panels). Local neuronal network fragmentation was indicated by the white arrows (right panels). Neurons were stained with anti-MAP2 antibody and observed in sample fields under fluorescent microscope (magnification $\mathrm{x} 40$ ).

from non-Tg mice resulted changed since convolutions and swellings in the terminal part of the processes were clearly evident (Fig. 9). On the contrary, the exposure to $\mathrm{A} \beta_{42}(0.5 \mu \mathrm{M} ; 24 \mathrm{~h})$ failed to affect the morphology of cultured astrocytes from $3 \times \mathrm{Tg}-\mathrm{AD}$ mice (data not shown). To quantify the effect of $A \beta_{42}$ exposure, the number of vital GFAP immunostained cultured astrocytes from non-Tg mice was determined. As shown in Fig. 10, the number of astrocytes was significantly higher in cell cultures exposed to $\mathrm{A} \beta_{42}$ than in control cultures. Pretreatment with PEA $(0.1 \mu \mathrm{M})$, by itself ineffective, counteracted the $A \beta_{42}$-induced decrease of neuron number (Fig. 10).

\section{DISCUSSION}

In the present study we compared, for the first time, the effects of $A \beta_{42}$ exposure on cell viability and glutamatergic transmission in primary cultures of cerebral cortex neurons and primary cultures of cerebral cortex astrocytes from 3xTg-AD and non-Tg (i.e., wild-type) mice. Moreover, the possible protective role of PEA against $A \beta_{42}$ toxicity was also evaluated in $3 \times T g-A D$ and non-Tg mouse cell cultures.

\section{Primary cultures of cerebral cortex neurons}

As expected, treatment with $\mathrm{A} \beta_{42}$ caused degeneration in cortical neurons obtained from non-Tg mice, as demonstrated by the biochemical and morphological approaches. In particular, after $24 \mathrm{~h}$ of $\mathrm{A} \beta_{42}$ exposure, a very small, but significant, decrease in cell viability was observed, and this effect was also associated with a reduction of vital MAP-2 immunostained cultured neuron number. This latter parameter has been used as an index of neurodegeneration since MAP-2 cytoskeletal protein, predominantly expressed in neurons, plays important roles in the outgrowth of neuronal processes, synaptic plasticity, and neuronal cell death. Staining of the neurites with MAP-2 


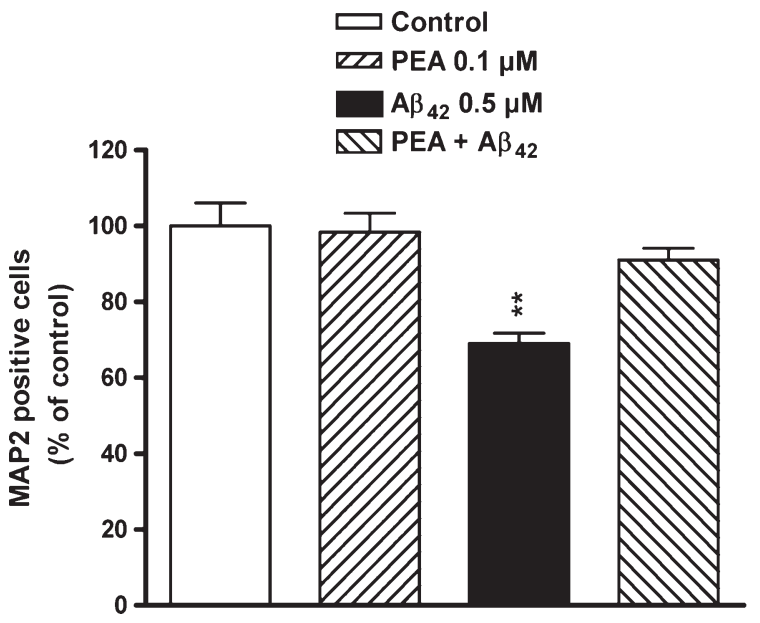

Fig. 4. Effects of $A \beta_{42}$ exposure $(0.5 \mu \mathrm{M} ; 24 \mathrm{~h})$, alone or in combination with PEA $(0.1 \mu \mathrm{M})$, on the number of MAP2 positive cells in primary cultures of cerebral cortical neurons from non$\mathrm{Tg}$ mice. Neurons were stained with anti-MAP2 antibody and observed under fluorescent microscope. Each histograms represents the mean \pm S.E.M. $(n=8 / 12){ }^{* *} p<0.01$ significantly different from control, PEA and PEA $+\mathrm{A} \beta_{42}$ groups according to analysis of variance followed by the Newman-Keuls test for multiple comparisons.

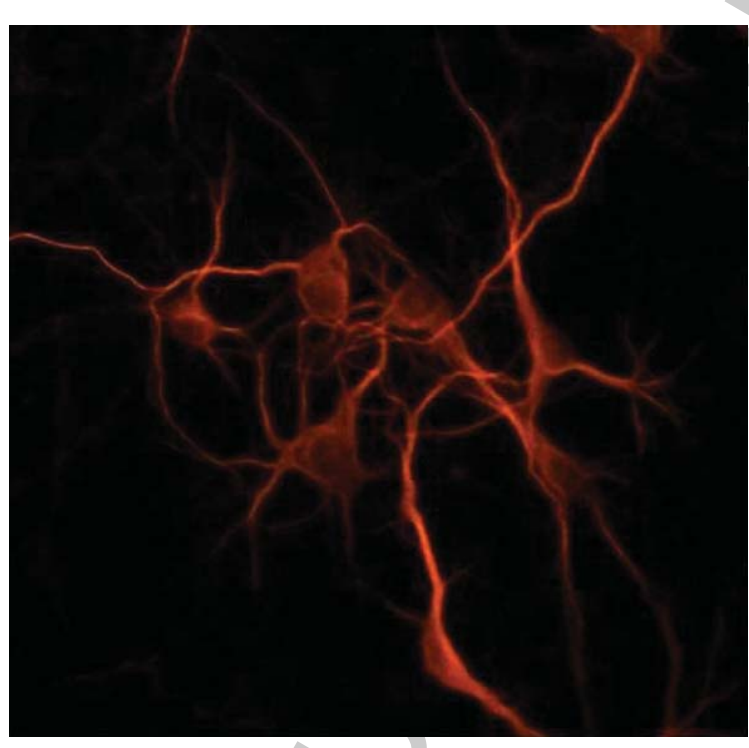

Fig. 5. Representative fluorescence photomicrographs of MAP2 immunoreactivity in primary cultures of cerebral cortical neurons from 3xTg-AD mice. Neurons were stained with anti-MAP2 antibody and observed in sample field under fluorescent microscope (magnification x20).

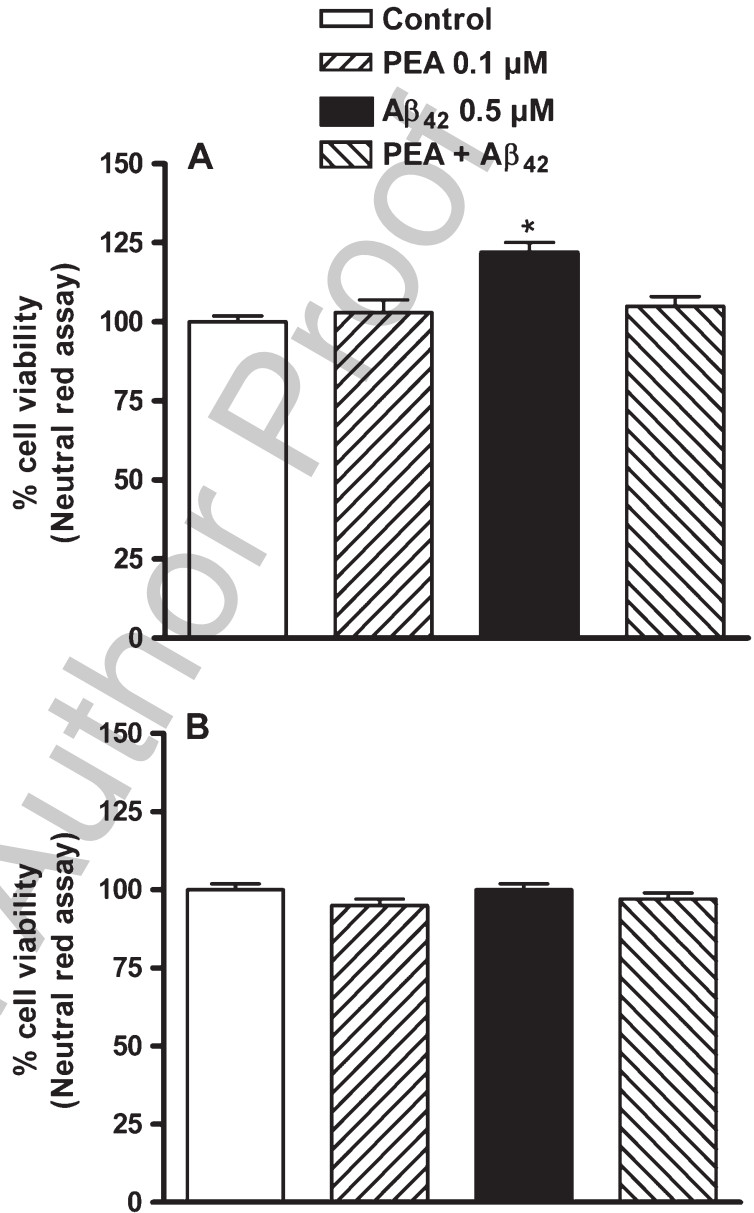

Fig. 6. Effects of $A \beta_{42}$ exposure $(0.5 \mu \mathrm{M} ; 24 \mathrm{~h})$, alone or in combination with PEA $(0.1 \mu \mathrm{M})$, on cell viability in primary cultures of cerebral cortical astrocytes from non-Tg (A) and 3xTg-AD (B) mice. PEA was added $1 \mathrm{~h}$ before $A \beta_{42}$ and maintained in contact with the cells during $A \beta_{42}$ exposure $(24 \mathrm{~h})$. Cell viability was assessed by Neutral red assay and expressed as percentage of control values. Each histogram represents the mean \pm S.E.M. $(n=30-40) .{ }^{*} p<0.05$ significantly different from control, PEA and PEA $+\mathrm{A} \beta_{42}$ groups according to analysis of variance followed by the Newman-Keuls test for multiple comparisons.

induced by $A \beta_{42}$ in the neurite development observed in the present study is in agreement with recent data, reporting that axon degeneration in cultured hippocampal neurons is a key component of neuronal death following $\mathrm{A} \beta_{42}$ exposure [42]. Furthermore, a microtubule deregulation after $A \beta_{42}$ treatments has been observed in other studies. In particular, Mota et al. [43] documented $A \beta_{42}$-induced decreases in total and polymerized levels of $\beta$-III tubulin along with polymerized $\alpha$-tubulin, and these alterations were correlated with a reduced neurite length. Finally, $A \beta_{42}$-induced microtubule depletion and loss of spines [44] as well as a retraction of synaptic contacts [45] were also observed. 

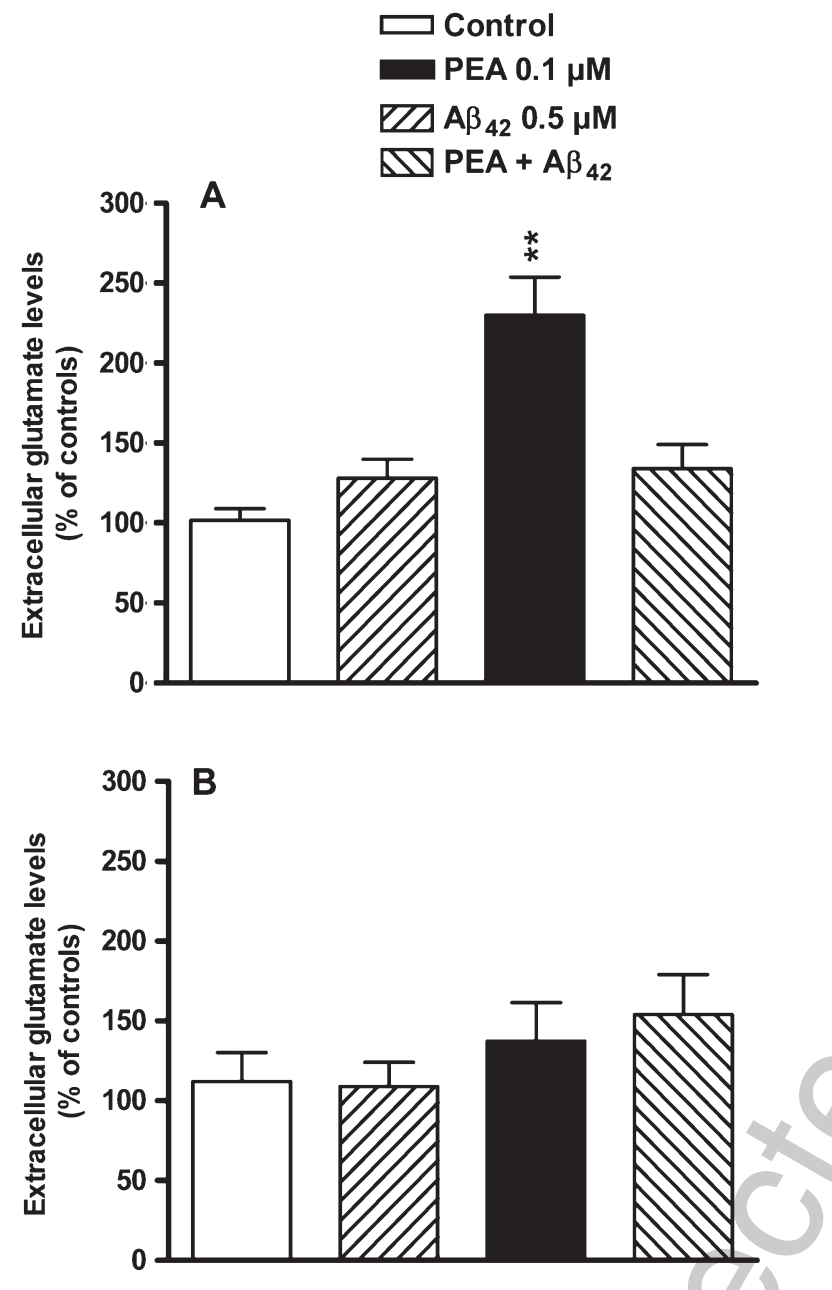

Fig. 7. Effects of $A \beta_{42}$ exposure $(0.5 \mu \mathrm{M} ; 24 \mathrm{~h})$, alone or in combination with PEA $(0.1 \mu \mathrm{M})$, on extracellular glutamate levels in primary cultures of cerebral cortical astrocytes from non- $\mathrm{Tg}(\mathrm{A})$ and $3 \mathrm{xTg}-\mathrm{AD}(\mathrm{B})$ mice. PEA was added $1 \mathrm{~h}$ before $\mathrm{A} \beta_{42}$ and maintained in contact with the cells during $A \beta_{42}$ exposure $(24 \mathrm{~h})$. Each histograms represents the mean \pm S.E.M. $(n=32-42)$. ${ }^{* *} p<0.01$ significantly different from control, PEA and PEA $+\mathrm{A} \beta_{42}$ groups according to analysis of variance followed by the Newman-Keuls test for multiple comparisons. glutamate efflux from cortical neurons. At this regard, several studies showed synaptic dysfunction associated with $A \beta_{42}$ exposure, particularly at presynaptic level [46-50]. Deleterious effects of $A \beta_{42}$ on multiple steps of synaptic vesicle trafficking, leading to weaken synaptic transmission have also been reported [51]. $\mathrm{A} \beta_{42}$-treated neurons also displayed reduced number of synaptic vesicles and a reduction in several presynaptic proteins [52]. A reduction in the density of the vesicular glutamate transporter 1 (VGluT1) and a decrease in the number of vGluT1-immunopositive hippocampal nerve terminals were observed in a mouse model of AD [53], suggesting a particular susceptibility of glutamatergic nerve terminals to $A \beta_{42}$-induced toxicity. In fact, intracellular accumulation of $A \beta$ dramatically affects glutamatergic synaptic function at both presynaptic and postsynaptic levels [54]. Finally, there is strong evidence for $A \beta_{42}$-induced impairments in mitochondrial transport, dynamics and function that contribute to synaptic degeneration $[47,55,56]$.

Interestingly, the exogenous $A \beta_{42}$-induced reductions of cell viability and extracellular glutamate levels were not observable in cortical cell cultures from $3 \mathrm{xTg}$-AD mice. The discrepancies between the results observed in cultured cells from the two genotypes could be due to the expression of endogenous intraand extra-neuronal $\mathrm{A} \beta$ peptides in $3 \times \mathrm{Tg}-\mathrm{AD}$ mousederived cell cultures. In fact, an early in vitro $A \beta$ overexpression associated with increased $A \beta_{42}$ levels was evident in cultured cortical neurons of 6 DIV obtained from 3xTg-AD mice [34]. Furthermore, an altered calcium homeostasis and decreased glutamatergic response were also observed in cultured cortical neurons from $3 \times \mathrm{Tg}-\mathrm{AD}$ mice $[34,57-59]$. In view of these data, it could be suggested that in the present study the exogenous $A \beta_{42}$ was ineffective in $3 \times T g-A D$ mice-derived cortical neurons as this cells at 8 DIV were already exposed to a quite high concentration of endogenous $A \beta$ fragments. This view is supported by i) the demonstration that control cultured cortical neurons obtained from 3xTg-AD mice displayed morphological alterations similar to those observed in $\mathrm{A} \beta_{42}$-exposed cultured cortical neurons obtained from non-Tg mice; ii) the evidence that basal extracellular glutamate levels in cortical cell cultures from $3 \times \mathrm{Tg}$ AD mice were significantly lower than those measured in non-Tg mouse cultured neurons. This finding is in line with previous data demonstrating a modification of the plasma membrane electrical excitability, leading to changes on synaptic function and consequently on glutamate transmission [34]. Furthermore, in vivo microdialysis studies reported a significant decrease els. The damage of nervous terminals could, in fact, impair the exocytotic mechanisms, leading to reduced

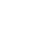

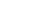

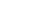

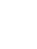
(1)

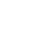

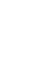

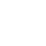
4 5

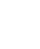
0

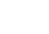
. 4

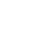

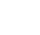

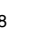

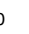

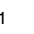
. 44

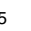

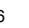
. .

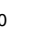
.

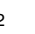

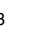

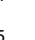

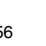
57

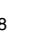

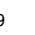

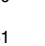
(a) 563 

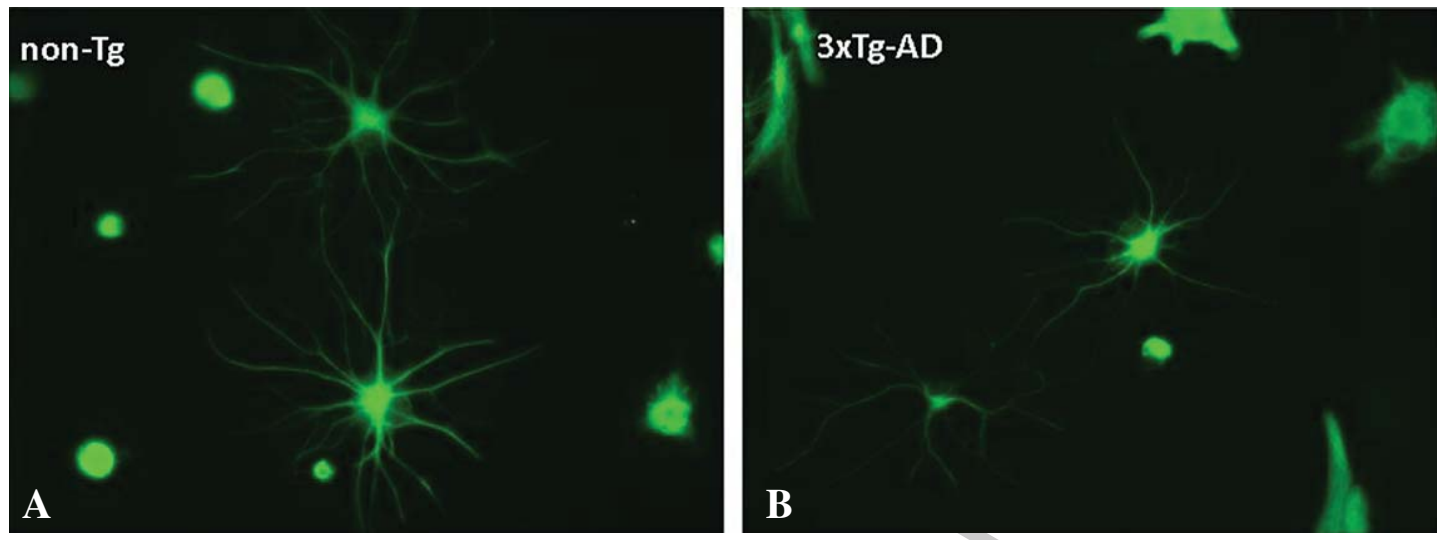

Fig. 8. Representative fluorescence photomicrographs of GFAP immunoreactivity in primary cultures of cerebral cortical astrocytes from non$\mathrm{Tg}(\mathrm{A})$ and $3 \mathrm{xTg}-\mathrm{AD}(\mathrm{B})$ mice. Astrocytes were stained with anti-GFAP antibody and observed in sample field under fluorescent microscope (magnification $\times 40$ )

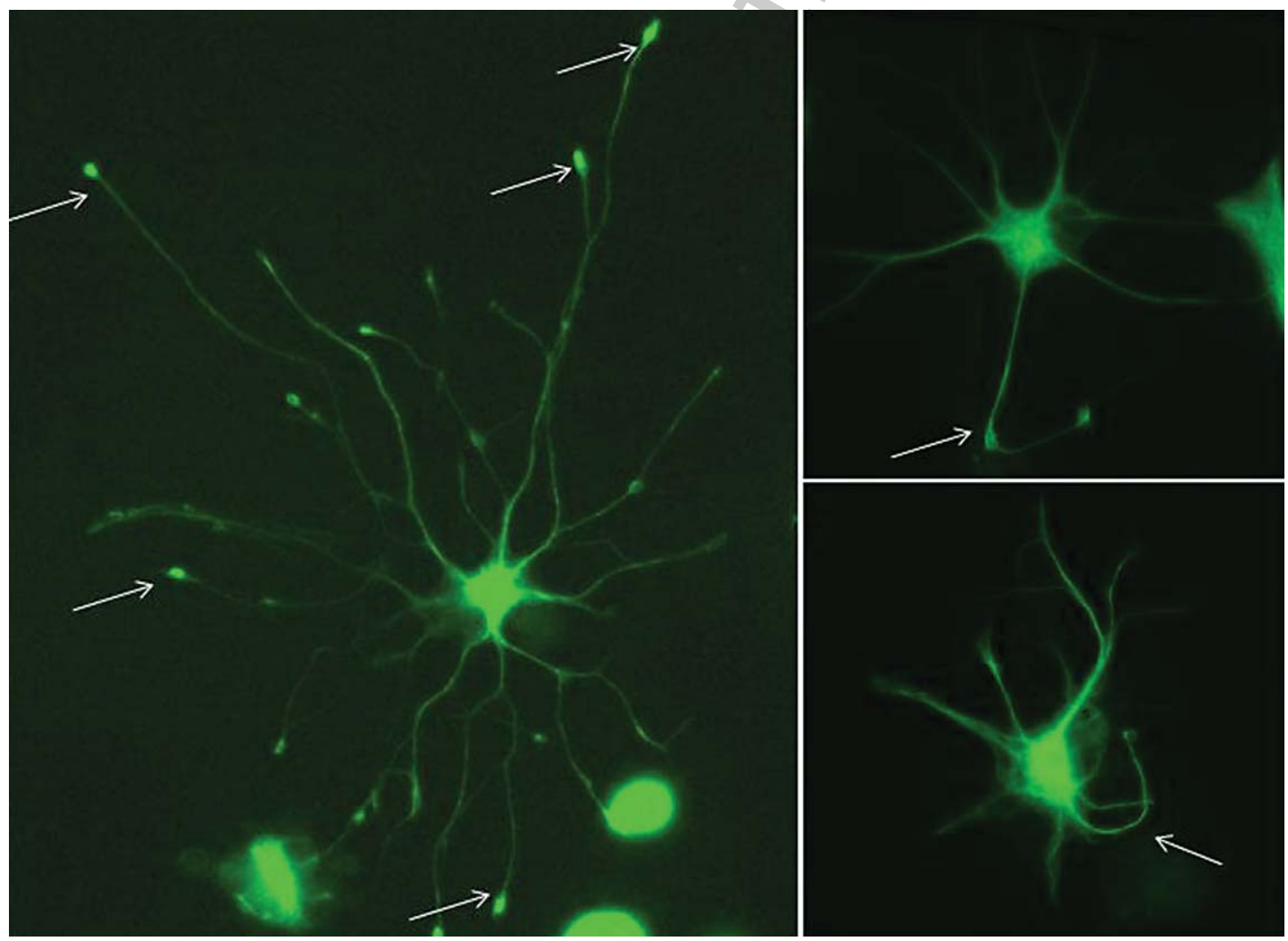

Fig. 9. Representative fluorescence photomicrographs of GFAP immunoreactivity in primary cultures of cerebral cortical astrocytes from non$\mathrm{Tg}$ mice after $24 \mathrm{~h}$ of $\mathrm{A} \beta_{42}(0.5 \mu \mathrm{M})$ exposure. Alterations of the morphology are indicated by the white arrows. Astrocytes were stained with anti-GFAP antibody and observed in sample fields under fluorescent microscope (magnification $\times 40$ ).

of basal glutamate release in the frontal cortex and hippocampus of 18-month-old 3xTg-AD-mice [36] and a reduction of $\mathrm{KCl}$-stimulated glutamate release in the hippocampus of 17-month-old APdE9 mice
[60]. Interestingly for the possible translational aspects of the present findings, there are data in literature reporting reduced glutamate tissue levels in $\mathrm{AD}$ brains [60-62]. 


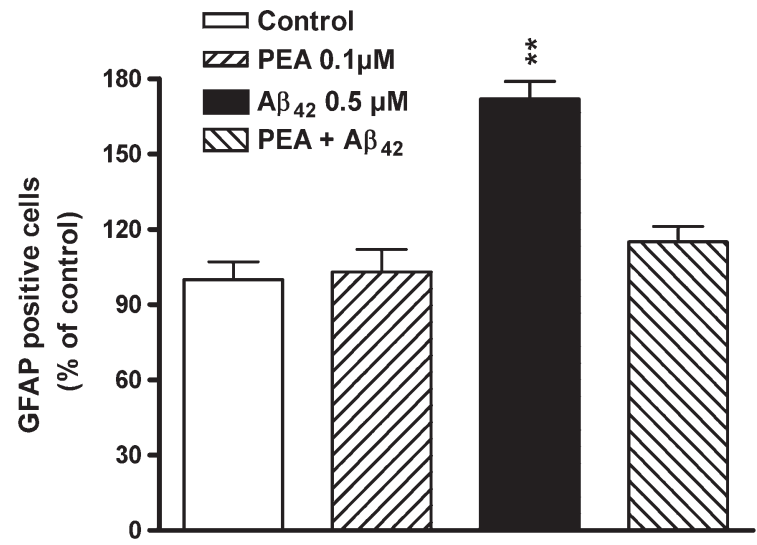

Fig. 10. Effects of $A \beta_{42}$ exposure $(0.5 \mu \mathrm{M} ; 24 \mathrm{~h})$, alone or in combination with PEA $(0.1 \mu \mathrm{M})$, on the number of GFAP positive cells (expressed as percentage of control value) in primary cultures of cerebral cortical astrocytes from non-Tg mice. Astrocytes were stained with anti-GFAP antibody and observed under fluorescent microscope. Each histograms represents the mean \pm S.E.M $(n=8 / 12) .{ }^{* *} p<0.01$ significantly different from control, PEA and $\mathrm{PEA}+\mathrm{A} \beta_{42}$ groups according to analysis of variance followed by the Newman-Keuls test for multiple comparisons.

mediators [67]. Interestingly, similar alterations have been observed in 1-12 months $3 \times \mathrm{Tg}$-AD mouse astrocytic morphology $[68,69]$, but not in the present study. These $A \beta_{42}$-induced effects probably indicated a rearrangement of cytoskeleton filaments, which could modify the functionality of astrocytes. It has been shown that in pathological conditions, such as in AD, the activated glial cells produce inflammatory mediators, including TNF- $\alpha$ and prostaglandin E2, which increase intracellular $\mathrm{Ca}^{2+}$ levels in astrocytes, leading to the release of gliotransmitters, such as glutamate [70]. In view of these findings, the effects of $A \beta_{42}$ on astrocyte functionality have been assessed by evaluating extracellular glutamate levels. The exposure of non-Tg mouse cultured astrocytes to $A \beta_{42}$ (24 h) significantly increased extracellular glutamate levels. A previous study demonstrated that astrocytes exposed (72 h) to $10 \mu \mathrm{M} \mathrm{A} \beta_{25-35}$ exhibit increased glutamate release [71]. This effect could be due at least to two different mechanisms. Firstly, $A \beta_{42}$ could cause the release of pro-inflammatory cytokines by cultured astrocytes $[29,67,71]$ along with a consequent increase of intracellular $\mathrm{Ca}^{2+}$ levels leading to exocytotic glutamate release. Secondly, $A \beta_{42}$ could decrease glutamate uptake [72] and compromise the activity of glutamate transporters GLT-1 and GLAST [73, 74], thus reducing glutamate reuptake. Previous studies reported a significant reduction in the activity of glutamate transporters in human AD tissues [75, 76] and in animal models of AD [77, 78]. Based on these data, we expected to observe higher basal glutamate levels in cultured astrocyte from $3 \mathrm{xTg}-\mathrm{AD}$ mice than in those from non-Tg mice. Surprisingly, an opposite result was obtained. This finding could be the consequence of increased glutamate reuptake in this specific animal model of AD. In fact, an increase of GLT1 expression has been shown in frontal cortex of 3xTgAD mice [36]. Differently, Kulijewicz-Nawrot et al. [79] did not find any changes in the expression of GLT1 in prefrontal cortex astrocytes from 3xTg-AD mice. However, other mechanisms could underlie the reduction of basal glutamate levels in cultured astrocytes from $3 \mathrm{xTg}-\mathrm{AD}$ mice and other experiments will be necessary to explain this phenomenon.

As observed in primary cultures of cerebral cortex neurons, $A \beta_{42}$-induced effects on extracellular glutamate levels, cell viability, and cell morphology have not been detected in $3 \mathrm{xTg}$-AD mouse cultured astrocytes. The loss of responsiveness to a challenge with $A \beta_{42}$ in astrocytes from 3xTg-AD mice was already observed in a recent work [63]. In particular, these authors observed significant effects of 
$A \beta_{42}$ exposure on the expression of mGluR5 and inositol 1,4,5-trisphosphate receptor type 1 as well as on parameters of metabotropically stimulated $\left[\mathrm{Ca}^{2+}\right] \mathrm{i}$ transients in entorhinal cortex and hippocampal astrocytes derived from non-Tg mice. These effects were absent in entorhinal cortex and hippocampal astrocytes derived from $3 x T g-A D$ mice. Furthermore, they demonstrated that senile plaque formation in $3 \times \mathrm{Tg}$ $\mathrm{AD}$ mice triggers astrogliosis in hippocampal but not in entorhinal cortex astrocytes. The authors suggested that the expression of AD-related mutant genes in the transgenic mice could deregulate $\mathrm{Ca}^{2+}$ homeostasis and signaling in astroglia [63]. Therefore, we may speculate that also a deregulation in some pathways regulating glutamate release/efflux could be responsible of the lack of $A \beta_{42}$ effect in the cultured astrocytes from the animal model of $\mathrm{AD}$.

\section{PEA-induced protection against $A \beta_{42}$ toxicity}

An anti-inflammatory neuroprotective role has been suggested for the endogenous fatty acid amide PEA, member of N-acyl-ethanolamines [22, 23, 26, 32, 80]. Furthermore, a recent study reported that PEA, by activating PPAR- $\alpha$, rescues altered molecular pathways as well as behavioral impairments that can mimic some early traits of AD. Based on these findings, in the present study the possible protective role of PEA against $A \beta_{42}$ toxicity has been also investigated in primary cultures of cortical neurons and astrocytes from both the mouse genotypes.

PEA pretreatment counteracts the reduction of cell viability induced by $A \beta_{42}$ in cultured cortical neurons from non- $\mathrm{Tg}$ mice. These data were in agreement with previous morphological and biochemical studies, showing that PEA pretreatment significantly reduced $\mathrm{A} \beta_{42}$-induced neuronal loss in rat organotypic hippocampal slice cultures and rat neuronal cultures [24, 31]. The present results also suggested protective effects of PEA in non-Tg mouse cultured cortical astrocytes, where the compound was able to prevent the $\mathrm{A} \beta_{42}$-induced cell proliferation. A similar result has been recently obtained in rat organotypic hippocampal slice cultures exposed to $A \beta_{42}$ [30]. Furthermore, evidence that PEA reduced the astrocytic production of proinflammatory molecules and cytokine release in an in vitro model of $\mathrm{A} \beta$ neurotoxicity, has been also provided [29]. Interestingly, the present study also described, for the first time, a protective effect of PEA pretreatment on the $A \beta_{42}$-induced alterations of glutamatergic signaling, observed both in cultured neurons and in cultured astrocytes from non-Tg mice. Overall, these results suggest that PEA could be effective in preventing not only the $A \beta_{42}$-induced cell death, but also the loss of functionality of cortical neurons and astrocytes triggered by the exposure to the peptide. Further studies are necessary for elucidating the possible involvement of PPARs, GPR55, CB2, or other receptors in the protective effects of PEA. However, recent studies suggest some possibilities. Thus, the neuroprotective effect of PEA could be dependent on its ability to counteract the inflammatory processes, through the activation of the anti-inflammatory nuclear receptor PPAR- $\alpha$ and the consequent gene expression regulation [30]. Furthermore, PEA by activating PPAR- $\alpha$ could enhance the number of peroxisomes and/or the activity of the peroxisomal matrix protein catalase counteracting the redox perturbation following the $A \beta$ excess [32].

In the present study, we propose that the lack of $\mathrm{A} \beta_{42}$-induced toxicity in cultured cells from $3 \mathrm{xTg}-\mathrm{AD}$ mice could be ascribed to the expression of endogenous intra- and extra-neuronal $\mathrm{A} \beta$ peptides in this in vitro animal model of AD (see above). Thus, one would expect that PEA exerted by itself positive effects on cell viability and functionality in primary cultures of cerebral cortex neurons and astrocytes from $3 \mathrm{xTg}-\mathrm{AD}$ mice. On the contrary, the present results demonstrated that PEA did not display any effects on cell viability and extracellular glutamate levels in cultured cortical neurons from $3 \times \mathrm{Tg}-\mathrm{AD}$ mice. A possible explanation of this result is that, in this study, the cultures were used after $8 \mathrm{DIV}$, while early in vitro $\mathrm{A} \beta$ overexpression associated with increased $A \beta_{42}$ levels was already evident in cultured cortical neurons of 6 DIV obtained from 3xTg-AD mice [34]. Furthermore, previous studies have demonstrated that the expression of fatty acid amide hydrolase (FAAH) enzyme is elevated in astrocytes in AD [81] and in Down's syndrome, sometimes referred to as a human model of $\mathrm{AD}$-like $\mathrm{A} \beta$ deposition [82]. This could also contribute to the lack of effects of PEA, which is a substrate of FAAH in cultured astrocytes obtained from transgenic mice.

\section{CONCLUSIONS}

The present study indicates that PEA exerts differential effects against $\mathrm{A} \beta$-induced toxicity in primary cultures of cortical neurons and astrocytes from non$\mathrm{Tg}$ (wild-type) and 3xTg-AD mice. In particular, PEA displays protective properties in wild-type mouse cell cultures but not in 3xTg AD mouse neuronal cultured cells overexpressing $A \beta$. Taken together, these find- 
ings suggest that the compound may be effective in the early $\mathrm{AD}$ or when $\mathrm{A} \beta$ is accumulating and initiating damage in the central nervous system. In this context, it will be relevant to evaluate the effects of PEA on cellular viability and glutamate release in vitro choosing a period of exposure of the $3 \times \mathrm{Tg}$-AD mouse neurons to the toxic peptide preceding the development of $A \beta$ accumulation and tau hyperphosphorylation [34, 83].

\section{ACKNOWLEDGMENTS}

This work was supported by a grant to ST from the Italian Ministry of Instruction, University and Research (MIUR; PRIN 2009NKZCNX 002 ). The authors thank the "IRET Foundation" for the technical support.

Authors' disclosures available online (http://jalz.com/manuscript-disclosures/14-3039r2).

\section{REFERENCES}

[1] Fuller S, Steele M, Münch G (2010) Activated astroglia during chronic inflammation in Alzheimer's disease-do they neglect their neurosupportive roles? Mutat Res 690, 40-49.

[2] Sun X, Jin L, Ling P (2012) Review of drugs for Alzheimer's disease. Drug Discov Ther 6, 285-290.

[3] Rubio-Perez JM, Morillas-Ruiz JM (2012) A review. Inflammatory process in Alzheimer's disease, role of cytokines Scientific World Journal 2012, 756357.

[4] Jung ES, An K, Hong HS, Kim JH, Mook-Jung I (2012) Astrocyte-originated ATP protects $A \beta 1-42$-induced impairment of synaptic plasticity. J Neurosci 32, 3081-3087.

[5] Ballard C, Gauthier S, Corbett A, Brayne C, Aarsland D, Jones E (2011) Alzheimer's disease. Lancet 377, 1019-1031.

[6] Gustaw-Rothenberg K, Lerner A, Bonda DJ, Lee HG, Zhu X, Perry G, Smith MA (2010) Biomarkers in Alzheimer's disease: Past, present and future. Biomark Med 4, 15-26.

[7] Muirhead KE, Borger E, Aitken L, Conway SJ, Gunn-Moore FJ (2010) The consequences of mitochondrial amyloid betapeptide in Alzheimer's disease. Biochem J 426, 255-270.

[8] Kofalvi A, Vizi ES, Ledent C, Sperlagh B (2003) Cannabinoids inhibits the release of $[3 \mathrm{H}]$ glutamate from rodent hippocampal synaptosomes via a novel CB1 receptorindependent action. Eur J Neurosci 18, 1973-1978.

[9] Rivest S (2006) Cannabinoids in microglia: A new trick for immune surveillance and neuroprotection. Neuron 49, 4-8.

[10] Li C, Zhao R, Gao K, Wei Z, Yin MY, Lau LT, Chui D, Hoi Yu AC (2011) Astrocytes: Implications for neuroinflammatory pathogenesis of Alzheimer's disease. Curr Alzheimer Res $\mathbf{8}$ 67-80.

[11] Perry VH, Nicoll JA, Holmes C (2010) Microglia in neurodegenerative disease. Nat Rev Neurol 6, 193-201.

[12] Sastre M, Walter J, Gentleman SM (2008) Interactions between APP secretases and inflammatory mediators. $\mathrm{J} \mathrm{Neu}$ roinflammation $\mathbf{5}, 25$.

[13] Fernández-Ruiz J, García C, Sagredo O, Gómez-Ruiz M, de Lago E (2010) The endocannabinoid system as a target for the treatment of neuronal damage. Expert Opin Ther Targets 14, 387-340
[14] Allaman I, Gavillet M, Bélanger M, Laroche T, Viertl D, Lashuel HA, Magistretti PJ (2010) Amyloid-beta aggregates cause alterations of astrocytic metabolic phenotype: Impact on neuronal viability. $J$ Neurosci 30, 3326-3338.

[15] Vesce S, Rossi D, Brambilla L, Volterra A (2007) Glutamate release from astrocytes in physiological conditions and in neurodegenerative disorders characterized by neuroinflammation. Int Rev Neurobiol 82, 57-71.

[16] Bisogno T, Di Marzo V (2008) The role of the endocannabinoid system in Alzheimer's disease: Facts and hypotheses. Curr Pharm Des 14, 2299-3305.

[17] Pazos MR, Núñez E, Benito C, Tolón RM, Romero J (2004) Role of the endocannabinoid system in Alzheimer's disease: New perspectives. Life Sci 75, 1907-1915.

[18] Bedse G, Romano A, Lavecchia AM, Cassano T, Gaetani S (2014) The role of endocannabinoid signaling in the molecular mechanisms of neurodegeneration in Alzheimer's disease. J Alzheimers Dis 43, 1115-1136.

[19] Campillo NE, Páez JA (2009) Cannabinoid system in neurodegeneration: New perspectives in Alzheimer's disease. Mini Rev Med Chem 9, 539-559.

[20] Ramírez BG, Blázquez C, Gómez del Pulgar T, Guzmán M, de Ceballos ML (2005) Prevention of Alzheimer's disease pathology by cannabinoids: Neuroprotection mediated by blockade of microglial activation. J Neurosci 25, 19041913.

[21] Costa B, Conti S, Giagnoni G, Colleoni M (2002) Therapeutic effect of the endogenous fatty acid amide, palmitoylethanolamide, in rat acute inflammation: Inhibition of nitric oxide and cyclo-oxygenase systems. Br J Pharmacol 137, 413-420.

[22] Esposito S, Cuzzocrea S (2013) Palmitoylethanolamide in homeostatic and traumatic central nervous system injuries. CNS Neurol Disord Drug Targets 12, 55-61.

[23] Esposito S, Cuzzocrea S (2013) Palmitoylethanolamide is a new possible pharmacological treatment for the inflammation associated with trauma. Mini Rev Med Chem 13, 237-255.

[24] Skaper SD, Facci L (2012) Mast cell-glia axis in neuroinflammation and therapeutic potential of the anandamide congener palmitoylethanolamide. Philos Trans $R$ Soc Lond B Biol Sci 367, 3312-3325.

[25] Moriconi A, Cerbara I, Maccarrone M, Topai A (2010) GPR55: Current knowledge and future perspectives of a purported "Type-3" cannabinoid receptor. Curr Med Chem 17, 1411-1429.

[26] Lo Verme J, Fu J, Astarita G, La Rana G, Russo R, Calignano A, Piomelli D (2005) The nuclear receptor peroxisome proliferator-activated receptor-alpha mediates the anti-inflammatory actions of palmitoylethanolamide. $\mathrm{Mol}$ Pharmacol 67, 15-19.

[27] O'Sullivan SE, Kendall DA (2010) Cannabinoid activation of peroxisome proliferator-activated receptors: Potential for modulation of inflammatory disease. Immunobiology $\mathbf{2 1 5}$, 611-616.

[28] Re G, Barbero R, Miolo A, Di Marzo V (2007) Palmitoylethanolamide, endocannabinoids and related cannabimimetic compounds in protection against tissue inflammation and pain: Potential use in companion animals. Vet J 173, 21-30.

[29] Scuderi C, Esposito G, Blasio A, Valenza M, Arietti P, Steardo L Jr, Carnuccio R, De Filippis D, Petrosino S, Iuvone T, Di Marzo V, Steardo L (2011) Palmitoylethanolamide counteracts reactive astrogliosis induced by $\beta$-amyloid peptide. J Cell Mol Med 15, 2664-2674. 
[30] Scuderi C, Valenza M, Stecca C, Esposito G, Carratú MR, Steardo L (2012) Palmitoylethanolamide exerts neuroprotective effects in mixed neuroglial cultures and organotypic hippocampal slices via peroxisome proliferator-activated receptor- $\alpha$. J Neuroinflammation $\mathbf{9}, 49$.

[31] Scuderi C, Steardo L (2013) Neuroglial roots of neurodegenerative diseases: Therapeutic potential of palmitoylethanolamide in models of Alzheimer's disease. CNS Neurol Disord Drug Targets 12, 62-69.

[32] D’Agostino G, Russo R, Avagliano C, Cristiano C, Meli R, Calignano A (2012) Palmitoylethanolamide protects against the amyloid- $\beta 25-35$-induced learning and memory impairment in mice, an experimental model of Alzheimer disease. Neuropsychopharmacology 37, 1784-1792.

[33] Oddo S, Caccamo A, Shepherd JD, Murphy MP, Golde TE, Kayed R, Metherate R, Mattson MP, Akbari Y, LaFerla FM (2003) Triple-transgenic model of Alzheimer's disease with plaques and tangles: Intracellular Abeta and synaptic dysfunction. Neuron 39, 409-421.

[34] Vale C, Alonso E, Rubiolo JA, Vieytes MR, LaFerla FM, Giménez-Llort L, Botana LM (2010) Profile for amyloid-beta and tau expression in primary cortical cultures from $3 \mathrm{xTg}-\mathrm{AD}$ mice. Cell Mol Neurobiol 30, 577-590.

[35] Billings LM, Oddo S, Green KN, McGaugh JL, LaFerla FM (2005) Intraneuronal Abeta causes the onset of early Alzheimer's disease-related cognitive deficits in transgenic mice. Neuron 45, 675-688.

[36] Cassano T, Serviddio G, Gaetani S, Romano A, Dipasquale P, Cianci S, Bellanti F, Laconca L, Romano AD, Padalino I, LaFerla FM, Nicoletti F, Cuomo V, Vendemiale G (2012) Glutamatergic alterations and mitochondrial impairment in a murine model of Alzheimer disease. Neurobiol Aging 33, 1121.e1-e12.

[37] Oddo S, Caccamo A, Kitazawa M, Tseng BP, LaFerla FM (2003) Amyloid deposition precedes tangle formation in a triple transgenic model of Alzheimer's disease. Neurobiol Aging 24, 1063-1070.

[38] Antonelli T, Tomasini MC, Fournier J, Mazza R, Tanganelli S, Pirondi S, Fuxe K, Ferraro L (2008) Neurotensin receptor involvement in the rise of extracellular glutamate levels and apoptotic nerve cell death in primary cortical cultures after oxygen and glucose deprivation. Cereb Cortex 18, 1748-1757.

[39] Repetto G, del Peso A, Zurita JL (2008) Neutral red uptake assay for the estimation of cell viability/cytotoxicity. Nat Protoc 3, 1125-1131.

[40] Ferraro L, Tomasini MC, Siniscalchi A, Fuxe K, Tanganelli $\mathrm{S}$, Antonelli T (2000) Neurotensin increases endogenous glutamate release in rat cortical slices. Life Sci 66, 927-936.

[41] Takahashi RH, Capetillo-Zarate E, Lin MT, Milner TA, Gouras GK (2013) Accumulation of intraneuronal $\beta$-amyloid 42 peptides is associated with early changes in microtubuleassociated protein 2 in neurites and synapses. LoS One 8 , e51965.

[42] Alobuia WM, Xia W, Vohra BP (2013) Axon degeneration is key component of neuronal death in amyloid- $\beta$ toxicity. Neurochem Int 63, 782-789.

[43] Mota SI, Ferreira IL, Pereira C, Oliveira CR, Rego AC (2012) Amyloid-beta peptide 1-42 causes microtubule deregulation through N-methyl-D-aspartate receptors in mature hippocampal cultures. Curr Alzheimer Res 9, 844-856.

[44] Zempel H, Thies E, Mandelkow E, Mandelkow EM (2010) Abeta oligomers cause localized $\mathrm{Ca}(2+)$ elevation, missorting of endogenous tau into dendrites, tau phosphorylation, and destruction of microtubules and spines. J Neurosci 30, 1193811950.
[45] Rönicke R, Mikhaylova M, Rönicke S, Meinhardt J, Schröder UH, Fändrich M, Reiser G, Kreutz MR, Reymann KG (2011) Early neuronal dysfunction by amyloid $\beta$ oligomers depends on activation of NR2B-containing NMDA receptors. Neurobiol Aging 32, 2219-2228.

[46] Cuello AC (2006) Intracellular and extracellular Abeta, a tale of two neuropathologies. Brain Pathol 15, 66-71.

[47] Calkins MJ, Manczak M, Mao P, Shirendeb U, Reddy PH (2011) Impaired mitochondrial biogenesis, defective axonal transport of mitochondria, abnormal mitochondrial dynamics and synaptic degeneration in a mouse model of Alzheimer's disease. Hum Mol Genet 20, 4515-4529.

[48] Mezler M, Barghorn S, Schoemaker H, Gross G, Nimmrich $\mathrm{V}$ (2012) A $\beta$-amyloid oligomer directly modulates P/Q-type calcium currents in Xenopus oocytes. Br J Pharmacol 165, 1572-1583.

[49] Quiroz-Baez R, Flores-Domínguez D, Arias C (2013) Synaptic aging is associated with mitochondrial dysfunction, reduced antioxidant contents and increased vulnerability to amyloid- $\beta$ toxicity. Curr Alzheimer Res 10 324-331.

[50] Mota SI, Ferreira IL, Rego AC (2014) Dysfunctional synapse in Alzheimer's disease - A focus on NMDA receptors. Neuropharmacology 76, 16-26.

[51] Park J, Jang M, Chang S (2013) Deleterious effects of soluble amyloid- $\beta$ oligomers on multiple steps of synaptic vesicle trafficking. Neurobiol Dis 55, 129-139.

[52] Parodi J, Sepúlveda FJ, Roa J, Opazo C, Inestrosa NC, Aguayo LG (2010) Beta-amyloid causes depletion of synaptic vesicles leading to neurotransmission failure. J Biol Chem 285, 25062514

[53] Canas PM, Simões AP, Rodrigues RJ, Cunha RA (2013) Predominant loss of glutamatergic terminal markers in a $\beta$-amyloid peptide model of Alzheimer's disease. Neuropharmacology 76, 51-56.

[54] Ripoli C, Cocco S, Li Puma DD, Piacentini R, Mastrodonato A, Scala F, Puzzo D, D’Ascenzo M, Grassi C (2014) Intracellular accumulation of amyloid- $\beta(A \beta)$ protein plays a major role in $\mathrm{A} \beta$-induced alterations of glutamatergic synaptic transmission and plasticity. J Neurosci 34, 12893-12903.

[55] Ferreira IL, Resende R, Ferreiro E, Rego AC, Pereira CF (2010) Multiple defects in energy metabolism in Alzheimer's disease. Curr Drug Targets 11, 1193-1206.

[56] Reddy PH, Manczak M, Mao P, Calkins MJ, Reddy AP, Shirendeb U (2010) Amyloid-beta and mitochondria in aging and Alzheimer's disease: Implications for synaptic damage and cognitive decline. J Alzheimers Dis 20(Suppl 2), S499S512.

[57] Stutzmann GE, Caccamo A, LaFerla FM, Parker I (2004) Dysregulated IP3 signaling in cortical neurons of knock-in mice expressing an Alzheimer's-linked mutation in presenilin1 results in exaggerated $\mathrm{Ca} 2+$ signals and altered membrane excitability. J Neurosci 24, 508-513.

[58] Stutzmann GE, Smith I, Caccamo A, Oddo S, Parker I, Laferla F (2007) Enhanced ryanodine-mediated calcium release in mutant PS1-expressing Alzheimer's mouse models. Ann NY Acad Sci 1097, 265-277.

[59] Smith IF, Hitt B, Green KN, Oddo S, LaFerla FM (2005) Enhanced caffeine-induced $\mathrm{Ca} 2+$ release in the $3 \times \mathrm{Tg}-\mathrm{AD}$ mouse model of Alzheimer's disease. J Neurochem 94, 17111718.

[60] Minkeviciene R, Ihalainen J, Malm T, Matilainen O, KeksaGoldsteine V, Goldsteins G, Iivonen H, Leguit N, Glennon J, Koistinaho J, Banerjee P, Tanila H (2008) Age-related 
decrease in stimulated glutamate release and vesicular glutamate transporters in APP/PS1 transgenic and wild-type mice. J Neurochem 105, 584-594.

[61] Hyman BT, Van Hoesen GW, Damasio AR (1987) Alzheimer's disease: Glutamate depletion in the hippocampal perforant pathway zone. Ann Neurol 22, 37-40.

[62] Lowe SL, Bowen DM, Francis PT, Neary D (1990) Ante mortem cerebral amino acid concentrations indicate selective degeneration of glutamate-enriched neurons in Alzheimer's disease. Neuroscience 38, 571-577.

[63] Grolla AA, Sim JA, Lim D, Rodriguez JJ, Genazzani AA, Verkhratsky A (2013) Amyloid- $\beta$ and Alzheimer's disease type pathology differentially affects the calcium signalling toolkit in astrocytes from different brain regions. Cell Death Dis 4, e623.

[64] Lü L, Mak YT, Fang M, Yew DT (2009) The difference in gliosis induced by $\beta$-amyloid and Tau treatments in astrocyte cultures derived from senescence accelerated and normal mouse strains. Biogerontology 10, 695-710.

[65] Verkhratsky A, Olabarria M, Noristani HN, Yeh CY, Rodriguez JJ (2010) Astrocytes in Alzheimer's disease. Neurotherapeutics 7, 399-412.

[66] Casal C, Serratosa J, Tusell JM (2004) Effects of beta-AP peptides on activation of the transcription factor NF-kappaB and in cell proliferation in glial cell cultures. Neurosci Res $\mathbf{4 8 ,}$ 315-323.

[67] Garwood CJ, Pooler AM, Atherton J, Hanger DP, Noble W (2011) Astrocytes are important mediators of $A \beta$-induced neurotoxicity and tau phosphorylation in primary culture. Cell Death Dis 2, e167.

[68] Olabarria M, Noristani HN, Verkhratsky A, Rodríguez JJ (2010) Concomitant astroglial atrophy and astrogliosis in a triple transgenic animal model of Alzheimer's disease. Glia 58, 831-838

[69] Yeh CY, Vadhwana B, Verkhratsky A, Rodríguez JJ (2011) Early astrocytic atrophy in the entorhinal cortex of a triple transgenic animal model of Alzheimer's disease. ASN Neuro 3, 271-279.

[70] Hamilton NB, Attwell D (2010) Do astrocytes really exocytose neurotransmitters? Nat Rev Neurosci 11, 227-238.

[71] Orellana JA, Shoji KF, Abudara V, Ezan P, Amigou E, Sáez PJ, Jiang JX, Naus CC, Sáez JC, Giaume C (2011) Amyloid $\beta$-induced death in neurons involves glial and neurona hemichannels. J Neurosci 31, 4962-4977.

[72] Abe K, Misawa M (2003) Amyloid beta protein enhances the clearance of extracellular L-glutamate by cultured rat cortical astrocytes. Neurosci Res 45, 25-31.

[73] Matos M, Augusto E, Oliveira CR, Agostinho P (2008) Amyloid-beta peptide decreases glutamate uptake in cultured astrocytes: Involvement of oxidative stress and mitogenactivated protein kinase cascade. Neuroscience 156, 898-910.

[74] Matos M, Augusto E, Machado NJ, dos Santos-Rodrigues A, Cunha RA, Agostinho P (2012) Astrocytic adenosine A2A receptors control the amyloid- $\beta$ peptide-induced decrease of glutamate uptake. J Alzheimers Dis 31, 555-567.

[75] Scott HL, Tannenberg AE, Dodd PR (1995) Variant forms of neuronal glutamate transporter sites in Alzheimer's disease cerebral cortex. J Neurochem 64, 2193-2202.

[76] Masliah E, Alford M, DeTeresa R, Mallory M, Hansen L (1996) Deficient glutamate transport is associated with neurodegeneration in Alzheimer's disease. Ann Neurol 40, 759-766.

[77] Masliah E, Alford M, Mallory M, Rockenstein E, Moechars D, Van Leuven F (2000) Abnormal glutamate transport function in mutant amyloid precursor protein transgenic mice. Exp Neurol 163, 381-387.

[78] Scott HL, Pow DV, Tannenberg AE, Dodd PR (2002) Aberrant expression of the glutamate transporter excitatory amino acid transporter 1 (EAAT1) in Alzheimer's disease. J Neurosci 22, RC206.

[79] Kulijewicz-Nawrot M, Syková E, Chvátal A, Verkhratsky A, Rodríguez JJ (2013) Astrocytes and glutamate homoeostasis in Alzheimer's disease: A decrease in glutamine synthetase, but not in glutamate transporter-1, in the prefrontal cortex. ASN Neuro 5, 273-282.

[80] Paterniti I, Impellizzeri D, Crupi R, Morabito R, Campolo M, Esposito E, Cuzzocrea S (2013) Molecular evidence for the involvement of PPAR- $\delta$ and PPAR- $\gamma$ in anti-inflammatory and neuroprotective activities of palmitoylethanolamide after spinal cord trauma. J Neuroinflammation 10, 20.

[81] Benito C, Nunez E, Tolon RM, Carrier EJ, Rabano A, Hillard CJ, Romero J (2003) Cannabinoid CB2 receptors and fatty acid amide hydrolase are selectively overexpressed in neuritic plaque-associated glia in Alzheimer's disease brains. $J$ Neurosci 23, 11136-11141.

[82] Núñez E, Benito C, Tolón RM, Hillard CJ, Griffin WS, Romero J (2008) Glial expression of cannabinoid CB(2) receptors and fatty acid amide hydrolase are beta amyloidlinked events in Down's syndrome. Neuroscience 151, 104-110.

[83] Alonso E, Vale C, Vieytes MR, Laferla FM, Giménez-Llort L, Botana LM (2011) 13-Desmethyl spirolide-C is neuroprotective and reduces intracellular $\mathrm{A} \beta$ and hyperphosphorylated tau in vitro. Neurochem Int 59, 1056-1065. 